\title{
Pattern of aural morbidity among children in a rural tertiary care hospital
}

\author{
Bijan Basak ${ }^{1}$, Gautam Dhar ${ }^{2}$, Ganesh Chandra Gayen ${ }^{3}$, Ritam Ray ${ }^{4}$ \\ 1. Assistant professor, Dept. of ENT, Burdwan Medical College \& Hospital, \\ P.O. - Rajbati, Burdwan - 713104, West Bengal, India \\ Associate professor, Department of Community Medicine, \\ Assistant director of Medical Education, Dept. of Health \& Family welfare, Govt of West Bengal, Swasthya \\ Bhawan, GN-29, Sector-5, Salt Lake City, Kolkata-700091, West Bengal, India \\ 3. Assistant professor, Dept. of ENT, Burdwan Medical College \& Hospital, \\ P.O. - Rajbati, Burdwan - 713104, West Bengal, India \\ 4. RMO-cum-clinical tutor, Dept. of ENT, Burdwan Medical College \& Hospital, \\ P.O. - Rajbati, Burdwan - 713104, West Bengal, India \\ Corresponding Author: Dr Ritam Ray
}

ABSTRACT : Objective: To study the pattern of aural morbidity among the paediatric population attending the ENT OPD of our hospital.

\section{Methods:}

DESIGN: Observational study with a cross-sectional design

SETTING: Tertiary government rural teaching hospital

PARTICIPANTS: All patients upto 15 years of age attending the ENT OPD during the study period

RESULTS: In our study, out of 3095 patients, 2062 were under the age of 15 years. Maximum patients $(36.47 \%)$ were within $0-5$ years of age. Out of them, 1036 patients $(50.24 \%)$ were male and rest 1026 patients (49.76\%) were female with a male female ratio of 1.01:1. Majority of patients were Hindu (53.98\%), rest $44.72 \%$ patients were Muslim and $1.3 \%$ were Christian. Chronic suppurative otitis media (37.54\%) was the most common ear pathology detected. $84.37 \%$ patients had tubo-tympanic type and rest (15.63\%) were having atticoantral type of disease. Other diseases were impacted wax (19.64\%), external otitis (15.13\%), ASOM (9.84\%), otomycosis (8.1\%), F.B. inside the ear (5.24\%), OME (3.93\%), preauricular sinus $(0.53 \%)$ and anotia with congenital aural atresia $(0.05 \%)$.

CONCLUSION: Ear diseases are one of the major health problems among children. Chronic suppurative otitis media followed by wax impaction and acute otitis media is the most common ear diseases in children attending the ENT OPD. Increasing awareness about ear diseases should be one of the goals of all health care providers. Improvement of health care facilities and awareness amongst health care providers would definitely be helpful in reducing the prevalence of ear diseases in developing countries like us

KEYWORDS : Aural morbidity; Children; CSOM; Wax; ASOM; External otitis; OME; Otomycosis 


\section{INTRODUCTION}

Ear is one of the most important special sensory organs and ear diseases are very common in our ENT practice. There is a fairly large amount of paediatric population attending ENT OPD of our hospital and out of them majority of patients were suffering from ear problems. There is a wide variation of presentation of ear diseases in paediatric population and it also varies from .

\section{MATERIALS AND METHODS}

This study was carried out in the Dept. of ENT , Burdwan Medical College \& Hospital, Burdwan. It comprises of 3195 patients aged below 15 years with 2062 patients having complaint related to their ear attended both OPD and emergencies of ENT Department of Burdwan Medical College \& Hospital, successfully treated during the period of December, 2012 to May, 2013. All the patients were evaluated carefully with thorough history taking and a complete ENT examination in ENT OPD after taking consent from the guardian of patients. Otoscopic examination done properly using otoscope.

\section{RESULTS}

In our study, 2062 patients were under the age of 15 years, presented with problem related with their ear out of 3095 patients in that age group, giving a prevalence of $66.62 \%$ of paediatric patients with otologic diseases. All the patients were divided into three broad groups, that is, 0-5 years, 6-10 years \& 11-15 years. Maximum patients (36.47\%) were within $0-5$ years of age. Out of them, 1036 patients (50.24\%) were male and rest 1026 patients $(49.76 \%)$ were female (Table -1$)$ with a male female ratio of 1.01:1. Majority of patients were Hindu (53.98\%), rest $44.72 \%$ patients were Muslim and $1.3 \%$ were Christian (Table - 4).Chronic suppurative otitis media (37.54\%) was the most common ear pathology detected among the patients and it is more common in 11-15 years age group (Table $-2 \& 5$ ). Out of 774 patients suffering from CSOM, 653 patients $(84.37 \%)$ were suffering from tubo-tympanic type and rest $(15.63 \%)$ were having attico-antral type of disease (Table -3$)$. Other diseases were impacted wax (19.64\%), external otitis (15.13\%), ASOM (9.84\%), otomycosis (8.1\%), F.B. inside the ear (5.24\%), OME (3.93\%), preauricular sinus $(0.53 \%)$ and anotia with congenital aural atresia $(0.05 \%)$.

\section{DISCUSSION}

Ear disease in children is a major public health problem in developing countries which can result in social and psychological problems for affected children and their families. The common leading causes of aural morbidities are chronic suppurative otitis media (CSOM) is a major health problem in developing countries throughout the world. It is the most common cause of persistent mild to moderate hearing impairment in children and young adults [1].

Ear is an important organ in the body that is very useful in day-to-day communication with the outside world, smooth performance of activities and social development. When this organ is diseased, it can result in impairment of function in hearing and balance.

CSOM is the most common morbid condition of the ear and a leading cause of hearing loss. Hearing loss is a significant health problem in developing countries $[2,3]$. In our study also, hearing loss due to chronic suppurative otitis media (37.54\%) was found to be the most common ear pathology detected. Akinpelu et al study showed that a very high prevalence $(33.9 \%)$ of CSOM in Nigerian children [4]. The reasons for this may include absence of regular screening programs for ear diseases, poverty, malnutrition, ignorance and paucity of accessible healthcare [5,6]. 
Wax impaction is the second most common morbidity in our study. Hatcher et al [7], Elangoet al [8] and Minza et al [9] reported prevalence rates of impacted wax ranging from $8.6 \%$ to $28.2 \%$. This is followed by otitis externa and ASOM. In the study done by Akinpelu and Amusa et al, however the frequency of ASOM was lower (7.0\%) [4]

The general observation of the patients' occupational classes showed that there were more patients in lower occupational classes than those in the upper classes. Generally, it is believed that people in upper socio-economic classes are more literate, have healthier lifestyles and behavior than people in lower classes [10]. Patients of lower socioeconomic status are likely to have nutritional problems and live in overcrowding environments which are important risk factors for the ear diseases. The patients in these classes are likely to delay seeking medical advice due to lack of knowledge about the disease and fund. They are likely to present with associated complications of the disease with increased morbidity.

The results from this study are only applicable to the paediatric population attending the ENT OPD of our hospital. An exact comparison with different socio economic and demographic factors could not be elicited as a control group was not taken into consideration. The prevalence of the various morbidities could be much higher in the general population, as many do not come to get medical help due to various socioeconomic barriers. Thus the results of this study cannot be generalized and applied to the community. A broader community based multicentred and large sample sized study is further needed to find out the actual prevalence and pattern of ear diseases in this country.

\section{V.TABLES}

Table - 1

Age distribution

\begin{tabular}{|l|l|l|l|}
\hline Age & Male (\%) & Female(\%) & Total \\
\hline $0-5$ yrs & $397(19.25 \%)$ & $355(17.22 \%)$ & $752(36.47 \%)$ \\
\hline 6-10 yrs & $288(13.97 \%)$ & $297(14.41 \%)$ & $585(28.37 \%)$ \\
\hline $11-15$ yrs & $351(17.02 \%)$ & $374(18.14 \%)$ & $725(35.16 \%)$ \\
\hline Total & $1036(50.24 \%)$ & $1026(49.77 \%)$ & 2062 \\
\hline
\end{tabular}

Table - 2

Distribution of patients by various diseases

\begin{tabular}{|l|l|l|}
\hline Disease & No. of patients & Percentage (\%) \\
\hline CSOM & 774 & 37.54 \\
\hline Impacted wax & 405 & 19.64 \\
\hline External otitis & 312 & 15.13 \\
\hline ASOM & 203 & 9.84 \\
\hline Otomycosis & 167 & 8.1 \\
\hline Foreign body ear & 108 & 5.24 \\
\hline OME & 81 & 3.93 \\
\hline Preauricular sinus & 11 & 0.53 \\
\hline $\begin{array}{l}\text { Anotia with congenital aural } \\
\text { atresia }\end{array}$ & 01 & 0.05 \\
\hline
\end{tabular}


Table - 3

Distribution of types of CSOM

\begin{tabular}{|l|l|l|}
\hline Types of CSOM & No. of patients & Percentage (\%) \\
\hline Tubotympanic & 653 & 84.37 \\
\hline Atticoantral & 121 & 15.63 \\
\hline
\end{tabular}

Table - 4

Distribution of patients by religion

\begin{tabular}{|l|l|l|}
\hline Religion & No. of patients & Percentage (\%) \\
\hline Hindu & 1113 & 53.98 \\
\hline Muslim & 922 & 44.72 \\
\hline Christian & 27 & 1.30 \\
\hline
\end{tabular}

Table -5

Age wise distribution of common paediatric ear pathologies

\begin{tabular}{|l|l|l|l|l|}
\hline Disease & $0-5 y r s$ & $6-10 y r s$ & $11-15 y r s$ & Chi Square- \\
CSOM & 207 & 340 & 227 & 57.425 \\
\cline { 1 - 4 } Impacted wax & 173 & 123 & 109 & df -6 \\
\cline { 1 - 3 } External Otitis & 85 & 134 & 93 & \\
\cline { 1 - 2 } & 96 & 64 & 46 & \\
& & & & \\
\hline
\end{tabular}

\section{CONCLUSION}

Ear diseases are one of the major health problems among children. Chronic suppurative otitis media followed by wax impaction and acute otitis media is the most common ear diseases in children attending the ENT OPD. Increasing awareness about ear diseases should be one of the goals of all health care providers. Improvement of health care facilities and awareness amongst health care providers would definitely be helpful in reducing the prevalence of ear diseases in developing countries like us.

\section{REFERENCES}

[1] Biswas AC, Joarder AH, Siddiquee BH. Prevalence of CSOM among rural school going children. Mymensingh Med J 2005;14:152-55.

[2] Olusanya BO, Okolo AA, Aderemi AA. Predictors of hearing loss in school entrants in a developing country. J Postgrad Med. 2004; 50(3):173-178.

[3] Olusanya BO, Okolo AA, Ijaduola GT. The hearing profile of Nigerian school children. Int J Pediatr Otorhinolaryngol. 2000; 55(3):173-179.

[4] Akinpelu OV, Amusa YB. Otological diseases in Nigerian children. The Internet J Otorhinolaryngol.2007,7:1.

[5] Rai S, Puliyel JM. Screening for auditory impairment in resource-poor countries. J Postgrad Med. 2004; 50(3):178-179.

[6] Fasunla AJ, Adeosun AA, Afolabi AO, Nwaorgu OG. Usefulness of 61ehavioural test of hearing as a rapid public health screening tool for infants. J Pediatr Neurol. 2011; 9(1):29-33

[7] Hatcher J, Smith A, Mackenzie I, Thompson S, Bal I,Macharia I et al. A prevalence study of ear problems in school children in Kiambu district, Kenya, May 1992. Int J Pediatr Otorhinolaryngol 1995;33:197-205.

[8] Elango S, Purohit GN, Hashim M, Hilmi R. Hearing loss and ear disorders in Malaysian school children.Int J Pediatr Otorhinolaryngol 1991; 22:75-80.

[9] Minja BM and Machemba A. Prevalence of otitis media, hearing impairment and cerumen impaction among schoolchildren in rural and urban Dar es Salaam, Tanzania. Int J Pediatr Otorhinolaryngol 1996;37:29-34.

[10] Isaacs SL, Schroeder SA. Class - The ignored determinant of the nation?s health. N Engl J Med. 2004; 351(11):1137-1142. 


\section{ABBREVIATIONS}

ASOM - Acute suppurative otitis media CSOM - Chronic suppurative otitis media OME - Otitis media with effusion

F.B. - Foreign body

ENT -Ear nose \& throat

OPD - Out patient department 